\title{
EKSISTENSI PERADILAN HAM TERHADAP PELANGGARAN HAM DI TIMOR TIMUR
}

\section{Musleb Herry}

Negara Indonesia adalah negara yang berdasarkan atas hukum ( rechtstaat ), dan tidak berdasarkan atas kekuasaan belaka (machststaat ). Ini mengandung arti bahwa negara, termasuk didalamnya Pemerintah dan lembaga-lembaga negara yang lain dalám melaksanakan tindakan apapun harus berdasarkan hukum atau harus dapat dipertanggungjawabkan seccara hukum. Prinsip dari sistem ini disamping tertuang didalam rumusan pasalpasalnya, jelas sejalan dan merupakan pelaksanaan dari pokok-pokok pikiran yang terkandung dalam pembukaan Undang-Undang Dasar 1945.

Sejalan dengan apa yang cliuraikan Imanuel Kant bahwa negara hukum mempunyai ciri-cirisebagai berikut (Ali Emran, 1994 : 120) :

a. adanya jaminan konstitusional atas hak-hak azasi manusia

b. adanya pemisahan/distribusi kekuasaan

c. pemerintahan berdasarkan hukuni (adanyai asas legalitas)

d. adanya peradilan (tata usaha negara) untuk menyelesaikan perselisihan atau adanya suatu peradilan yang bebas dan tidak terikat.

Sebagai negara yang berdasarkan atas hukum, Indonesia memiliki keempat ciri diatas.

Apabila kita amati pelaksanaan hak azasi manusia dinegara Indonesia sejak merdeka sampai sekarang dapat dikemukakan terjadinya pasang surut dalam pelaksanaan hak-hak tersebut. Hal ini disebabkan situasi politik yang berlaku di negara Indonesia dalam kurun waktu tertentu. Pernah terjadi dalam kurun waktu tertentu hak-hak warga negara di bidang yuridik-politik dapat dilakukan tanpa pembatasan-pembatasan. Akan tetapi dipihak lain juga pernah terjadi berlangsungnya pembatasan-pembatasan dalam pelaksanaan hak-hak warga negara. Dalam situasi demikian ini, titik berat kebijaksanaan cliletakkan kepada stabilitas nasional.

Persoalan Hak Azasi manusia yang muncul kepermukaan secara konsepsioanal tidak terlepas dari faktor empiris mengenai kehidupan rakyat di Eropa dan bersamaan itu muncul dan berkembang pula paham individualisme dan liberalisme. Walaupun demikian masalah Hak Azasi Manusia pada prinsipnya berlaku secara universal. Hanya saja aplikasinya sangat bervariasi sesuai dengan corak dan sikap dasar buclaya yang dianut oleh suatu bangsa. Hal ini dapat kita lihat sebagai perbandingan antara pelaksanaan Hak Azasi Manusia di Indonesia dengan pelaksanaan Hak azasi Manusia di negara-negara Eropa misalnya Amerika Serikat.

Secara umum, masalah Hak azasi Manusia selama ini /diketahui berasal clari konsep/pemikiran Barat. Pacla hal menurut sarjana Tata Negara dari Universitas Gajah -Mada Yogyakarta, "sesungguhnya penghormatan dan aplikasi Hak azasi Manusia tersebut telah dijunjung tinggi oleh rakyat dan pemerintah Indonesia mulai dari kerajaan Padjajaran, Majapahit, dan Sriwijaya"(Moch. Tolchah Mansoer, 1979 : 72).

\section{HAK AZASI MANUSIA MENURUT PERSPEKTIF UUD 1945 DAN AL QUR'AN.}

Secara garis besar Hak Azasi Manusia yang telah dijamin oleh konstitusi di negara Indonesia seperti apa yang didefinisikan oleh Prof Mariam Budihadjo ( Ali Emran, 1994 : 171) "Sebagai hak yang dimiliki manusia yang telah diperoleh dan dibawanya bersamaan dengan kelahirannya atau kehadirannya di clalam kehidupan masyarakat, dianggap bahwa beberapa hak itu dimilikinya tanpa perbedaan atas dasar bangsa, rasagama dan/atau jenis kelamin". Oleh karena itu HAM bersifat azasi dan universal.' Dasar dari semua hak azasi ialah bahwa manusia harus memperoleh kesempatan untuk berhubungan sesuai dengan bakat dan cita-citanya.

Pengakuan terhadap haka-hak azasi manusia di Indonesia dapat clilihat dalam rumusan Pembukaan Undang Undang Dasar 1945 diantaranya terdapat kalimat 
yang berbunyi "......kemerdekaan ialah hak segala bangsa.....".hal ini mengisyaratkan bahwa seluruh bangsa Indonesia berhak atas kemerdekaan dan kebebasan sesama bangsa. Oleh karena itu segala bentuk penindasan dan penjajahan harus dihapuskan. Selain itu rumusan tersebut secara tersurat menyatakan pengakuan terhadap hak-hak kemanusiaan dan hak-hak memperoleh keadilan. Begitu pula pasal-pasal dalam Undang Undang Dasar 1945 yang antara lain pasal 27,(2) bahwa "segala warga negara bersamaan kedudukannya di dalam hukum dan pemerintahan dan wajib menjunjung hukum dan pemerintahan dengan tidak kecualinya",Dengan pasal tersebut dinyatakan adanya keseimbangan antara hak dan kewajiban dan tidak ada diskriminasi diantara warga negara mengenai haknya maupun kewajibannya. Pasal ini memuat peraturan yang lebih luas dari pada Decklaration of Human Rights, karena yang diatur disini bukan hanya sekedar hak saja akan tetapi juga kewajiban untuk mentaati hukum. Demikian juga dengan pasal yang lain yaitu $28,29,30(1), 31 \cdot(1)$, 34.

Riwayat perjuangan dalam menegakkan Hak azasi Manusia begitu panjang. Dimulai sejak awal jaman Mesir kuno (kurang lebih $6000 \mathrm{SM}$ ) sebagai akibat kesewenangwenangan para penguasa yang bertindak otoriter. Sehingga rakyat dijadikan objek kepuasan nafsu kekuasaannya. Rakyat dianggap tidak bereksistensi baik dalam penilikan kekayaan, kebebasan, bahkan hidupnya. Karena pengalaman hidup yang begitu pahit dan menyakitkan akhirnya rakyatpun bangkit, perjuangan menegakkan eksistensinya sebagai manusia yang oleh Allah SWT telah dibekali hak yang sama antara satu dengan yang lainnya didunia ini.

Perjuangan Hak Azasi Manusia tak pemah berhenti, Socrates dan Plato (filosof dan negarawan yunani) dianggap pelopor dan peletak dasar pengakuan hak azasi manusia. Dari perjúangan-perjuangan tersebut melahirkan beberapa piagam (naskah) tentang Hak-hak yang menclasari kehidupan manusia yang bersifat universal dan azas, misalnya :

a. Magna Charta (1215)

Suatu clokumen yang mencatat beberapa hak yang diberikan oleh Raja John Lackland (Inggris) yang berupa jaminan perlindungan terhadap kaum bangsawan dan gereja.

b. Bill of Rights (1689)

Suatu undang-undang yang diterima oleh perlemen Inggris sesudah berhasil dalam perlawanan terhadap James II.

c. Declaration des driot de I'homme et du citujen

Suatu naskah yang dicetuskan pada permulaan revolusi Perancis sebagai perlawanan terhadap kesewenang-wenangan dari rezim lama, (pernyataan hak-hak manusia dan warga negara, 1789)

d. Bill of Rights (1789)

Suatu undang-undang perjuangan hak yang disusun oleh rakyat Amerika Serikat.

Gagasan ini banyak mempengaruhi terhadap perjuangan azasi manusia di Perancis pada tahun

yang sama.

e. Naskah perjuangan hak azasi Amerika Serikat.

Frnklin D. Rosevelt pada awal Perang Dunia II yang dikenal dengan istilah "The Four Freedoms", yaitu:

1. kebebasan untuk berbicara dan menyatakan pendapat (freedom of speech)

2. kebebasan beragama ( freedom from religion)

3. kebebasan dari ketakutan ( freedom from fear)

4. kebebasan dari kemelaratan (freedom from ivant)

Setelah Perang Dunia II akhirnya terwujud . keinginan untuk merumuskan hak-hak azasi manusia dalam suatu naskah Internasional, yaitu berhasil merumuskan pernyataan/pengakuan sedunia tentang Hak Azasi Manusia ( Universal Declaration of Human Rights ) oleh negara-negara yang tergabung dalam Perserikatan Bangsa-Bangsa ( PBB ) pada tanggal $10^{\prime}$ Desember 1945 yang merupakan tonggak pengakuan 
Hak Azasi Manusia oleh dunia Internasional. Yang pada pasal 1 nya dirumuskan bahwa" Setiap orang dilahirkán merdeka dan mempunyai martabat dan hak-hak yang sama. Mereka dikaruniai akal dan budi dan kehendaknya bergaul satu sama lain dalam persaudaraan". Pengakuan yang demikian dipertegas pula dalam pasal 7 yang menyatakan bahwa "Setiap orang berkedudukan sama terhadap hukum dan berhak dengan tidak boleh diadakan perbedaan apapun juga akan perlindungan yang sama dalam hak itu".

Berkenaandengan hal tersebutsering dikemukakan orang adanya suatu prinsip yang dinamakan Equality before the law atau kesamaan kedudukan di clalam hukum. Dalam arti bahwa hukum dan keadilan tidaklah begitu membedakan orang kaya yang melanggar hukum harus dihukum sama dengan simiskin yang bersalah memperkosa hukum.

Sedangkan Hak Azasi Manusia menurut agama (Qur'an) ialah manusia dalam hidupnya selalu menginginkan kebahagiaan dan kedamaian. Namun demikian manusia selalu menemui rintangan untuk mencapai maksud itu, disebabkan pelanggaran atas hakhak dan kebebasan asasinya oleh menusia lain. Apabila terjadi hal yang demikian itu, maka manusia harus kembali kepada konsepsi Al Qur'an. Hanya denga'n Al Qur'an dapat diatur dan dijamin kesejahteraan hidup manusia dari segala aspeknya misalnya dalam memperoleh hak hidup, kemerdekaan dan keamanan pribadi.

Karena sangat penting arti hidup ini bagi manusia Allah memandang bahwa melenyapkan hidup seseorang tanpa hak yang sama artinya melenyapkan semua manusia, karena orang itu adalah anggota masyarakat dan karena' membunuh seseorang itu berarti membunuh keturunanya, dan sebaliknya menyelamatkan kehidupan seseorang berarti telali menyelamatkan semua kehidupan manusia. Sebagaimana dijelaskan oleh Allah dalam firman-Nya :

Artinya :

"Barang siapa yanng membunuh seorang manusia, bukan karena orang itu (membunuh) orang lain atau bukan membuat kerusakan dimuka bumi, maka seakanakan dia telah membunuh seluruh manusia. Dan barang siapa yang memelihat kehidupan seorang manusia, maka seolah-olah dia telah memelihara kehidupan semua manusia: (Q.S Al-Maidah : 32)

Kemerdekaan itu adalah konsep yuridis yang didasari bukan atas dasar moral manusia semata, akan tetapi didasari oleh dekrit positif dari Allah SWT. Oleh karena itu menusia tidak boleh diperbudak (diperhamba) oleh menusia lain, tetapi hanya menjadi hamba dari Allah yang Maha Kuasa. Seperti firman-Nya :

\section{Artinya :}

"Kepada-Mu (wahai Allah) kami beribadat dan kepada-Mu kami memohon pertolongan"(Q.S Al-Fatihah :4).

Jadi hidup ini tidak ada artinya tanpa kemerdekaan dan keamanan pribadi. Hidup tanpa kemerdekaan dan keamanan sama artinya dengan membunuh perlahanlahan, disebabkan tidak dapatnya dia mengembangkan kehidupannya. Dan kemerdekaan itu adalah "tiap-tiap manusia merdeka berbuat menurut apa yang dikehendakinya, asal tidak melanggar kemerdekaan orang lain (Ahmad Amin, Al Akhlaq, alih bahasa Dalizar,1987 : 48). Artinya tidak ada halangan atas haknya untuk merdeka berbuat kecuali berdasarkan wewenang hukum dan peraturan.

\section{PERADIIAN HAK AZASI MANUSIA DI INDONESIA}

Setelah orde baru meninggalkan kita semua, ada beberapa yang masih tersisa sampai sekarang yaitu timbulnya kasus-kasus lama tentang Hak Azasi Manusia kepermukaan dan banyaknya kasus/pelanggaran baru yang mengarah pada disintegrasibangsa. Sejalan dengan era yang didengung-dengungkan oleh presiden Keempat Republik Indonesia yaitu era'reformasi dan era Demokrasi, maka luka-luka lama yang diderita oleh rakyat selama orde baru tersebut menganga kembali dan itu perlu dan harus dituntaskan atau diselesaikan sesegera mungkin demi tegaknya supremasi hukum dan negara demokrasi yang tengah dijalänkan ini.

Sebagai kasus yang telah terjadi di Indonesia misalnya Timor Timur, Aceh, Ambon, Makasar, 
Kalimantan Barat, Tanjungpriok sehingga kasus penyerbuan kantor PDI perjuangan di Jakarta 27 juli 1996 (kudatuli) hingga kini belum terselesaikan. Untuk menyelesaikan kasus-kasustersebut diperlukan sebuah badan peradilan dan perundang-undanganny: Ada sebagaian dari kasus itu dapat diselesaikan berdasarkan badan peradilan yang telah ditentukan dalam pasal 10 ayat 1 Undang-undang No, 14 tahun1970 tentang Ketentuan-ketentuan pokok Kekuasaan Kehakiman, dikatakanbahwa kekuasaan Kehakiman dilakukan oleh pengadilan dalam lingkungan (Bahariddin Lopa. 1993 : 2) :

a. Pengadilan Umum

b. Pengadilan Agama

c. Pengadilan Militer dan

d. Pengadilan Tata Usaha Negara.

Sebagaian lagi, yang terkait dengan kasus/pelanggaran Hak Azasi Manusia karena di Indonesia belum terbentuk badan peradilan Hak Azasi Manusia tersebut, maka perlu dibentuk badan tersebut beserta undang-undang yang mengatur mengenai pelanggaran Hak Azasi Manusia tersebut.

Perjalanan untuk membentuk pengadilan Hak Azasi Manusia masih panjang. Karena paket atau draf
Pada hal dalam sistem ketatanegaraan (asas-asas undang-undang Republik Indonesia) dan Internasional selama ini tidak mengenal dan tidak pernah ada bahwa undang-undang yang baru diundangkan itu berlaku surut. pakar dan praktisi hukum clan DPR akan memberlakukan undang-undanng ini nantinya berlaku surut (retroactive) tanpa batas waktu.

Pada hal dalam sistem ketatanegaraan (asas-asas undang-undang Republik Indonesia) dan Internasional selama ini tidak mengenal dan tidak pernah ada bahwa undang-undang yang baru diundangkan itu berlaku surut. Sehubungan dengan berlakunya undang-undang, kita mengenalbeberapa asas-asas perundang-undangan yang antara lain yaitu "Undang-undang tidak berlaku surut". Asas ini tercantum secara tegas didalam pasal 2 Algemene Bepalingen Van Wetgeving (A.B) yang menyatakan bahwa "suatu undang-undang itu hanya mengikat bagi masalah yang akan datang dan tidak mempunyai kekuatan berlaku suru" (Hartono Hadisoeprapto, 1993 : 25). Selain itu juga dipertegas lagi dalam pasal 1 ayat 1 Kitab Undang-undang Hukum Pidana (KUHPidana) sebagai berikut :"tiada suatu perbuatan dapat dipidana kecuali atas kekuatan aturan pidana dalam perundang-undangan yang telah ada sebelum perbuatan dilakukan". Atau dikenal denganasas "Nullum Delictum Noella Sine Praevia Lege Poenale" (Hartono Hadisoeprapto, 1993 : 25). Dari kedua pasal dan peraturan tersebut rancangan undang-undang (RUU) Pengadilan Hak Azasi Manusia itu baru selesai dibahas tim penyusun, 3 februari 2000 yang lalu. Bahkan masih baru rencana sekitar 20 februari ini konsep itu akan diajukan ke Dewan Perwaklan Rakyat (DPR). Itupun masih harus melalui beberapa tahap pembicaraan di DPR, dan itu jelas akan memakan waktu yang panjang.

Ada sedikit hal yang menarik(perlu dicermati) oleh kita semua, selain rancangan undang-undang itu akan mengatur ketentuan-ketentuan mengenai pembiaraan pelanggaran-pelanggaran (by omission) Hak Azasi Manusia dinegara kita mulai dari pembumi-hangusan Timor Timur pasca pendapat yang menuding keterlibatan militer Indonesia berada dibelakang semua itu, baru rancangan undang-undang (RUU) inilah berdasarkan kesepakatan antara tim penyusun RUU yang terdiri dari dapat disimpulakan bahwa suatu undang-undang hanya dapat diterapkan terhadap perbuatan yang terjadi sesudah peraturan/undang-undang itu berlaku atau diberlakukan.

Bagaimana dengan kasus-kasus (pelanggaran) Hak Azasi Manusia yang terjadi selama ini seperti di Timor Timur, Ambon, Aceh, Makasar, dan Kalimantan Barat? $\Lambda$ pakah dapat diselesaikan/diadili pelaku-pelaku dari kasus itu jika berdasarkan ketentuan-ketentuan diatas?

Untuk menjawab itu semua, mari kita lihat asal usul pembentukan Undang-Undang Peradilan Hak Ażasi Manusia. Berdasarkan tekanan dari masyarakat Aceh agar pemerintah segera mengadili para pelaku-pelaku pelanggaran Hak Azasi Manusia sewaktu masih cliberlakukan Daerah Oprasi Militer(DOM). Kesanggupan pemerintah itu menindak pelaku pelanggaran di Aceh itu dengan dikeluarkannya Keppres No. 88 tahun 1999 
yang diterbitkan pada tanggal 30 Juli 1999. Hanya dasar pelaksanaannya menggunakan Hukum nasional yaitu KUH Pidana pasal 89-pasal 94 tentang Peradilan Koneksitas.

Akan tetapi pelaksanaan dari ketentuan Keppres tersebut masih diragukan keindependenannya, karena itu mengadili para pelaku ( militer) juga diambil dari militer. Oleh karena itu dikeluarkanlah peraturan yang baru yaitu Perpu No. 1 tahun 1999 tentang Pengadilan Hak Azasi Manusia yang diterbitkan pada tanggal 8 oktober 1999. Sebagaian pasal dalam rancangan undangundangan pengadilan Hak Azasi Manusia itu. Menurut isi RUU, baik perangkat hukum maupun mekanismenya, minimal sudah sesuai dengan standart seperti yang diatur dalam hukum Internasional. Ketentuan Hak Azasi Manusianya juga secara Universal. Ini bisa diterima dalam pergaulan internasional terutama dalam penanganan kasus-kasus pelanggaran Hak Azasi Manusia.

Dalam draf pasal demi pasal terutama dalam draf VII pasal 37 ayat 1 RUU yang sebelumnya dalam pasal itu disebutkan bahwa "Terhadap pelanggaran Hak Azasi Manusia yang terjadisebelum berlakunya undang-undang ini, tetap diberlakukan ketentuan hukum pidana sebagaimana diatur dalam perundang-undangan yang berlaku. Akan tetapi dalam rapat pembahasan selanjutnya bunyi pasal tersebut kemudian dirubah menjadi "Terhadap pelanggaran Hak Azasi Manusia yang terjadi sebelum undang-undang ini, tetap diberlakukan ketentuan undang-undang ini".

Kemudian dalam pasal 37 ayat 2 disebutkan :Penyelesaian pelanggaran HAM sebagaimana dimaksud dalam ayat 1 tidak menutup kemungkinan penyelesaiannya dilaksanakan oleh Komisi Kebenaran dan Rekonsiliasi yang dibentuk berdasarkan undangundang" (forum Keadilan, 13 Februari 2000 : 18).

Dan pasal 32 Rancangan undang-undang mengatur "Penyelesaian pelanggaran Hak Azasi Manusia berat dimasa lalu akan dilakukan oleh Komisi Pencari Kebenaran dan Rekonsiliasi Nasional yang akan di bentuk berdasarkan UU".

Permasalahannya sekarang, dalam ketatanegaraan Indonesia maupun Internasional belum pernah ada suatu peraturan yang akan diberlakukan atau baru berlaku berlaku surut. Kalau hal ini terjadi (UU HAM) berlaku surut, maka ada hal yang anggap penulis menyimpang atau bertentangan dengan asas hukum yang berlaku :

1. Undang-Undang HAM cacat hukum karena bertentangan dengan asas hukum ketatanegaraan yang berlaku di negara kita saat ini.

2. Akan banyak kasus/pelanggaran yang harus diusut bahkan mungkin terhadap kasus-kasus yang terjadi mulai tahun 1966 atau bahkan tahun sebelumnya. Walaupun akan dibentuk Komisi Pencari Kebenaran dan Rekonsiliasi Nasional. Seperti yang dipergunakan oleh negara Afrika Selatan. Kalau tidak (dibatasi) tentunya akan menyulitkan bagi pihak pelaksana hukum, karena begitu banyak kasus lama yang harus diusut sedangkan kasus/pelanggaran baru belum terusut tuntás semuanya sampai saat ini.

3. Dalam Al Qur'an juga mengatakan bahwa :

Artinya :

"Dan kami (Allab) tidak akan meng'azab seseorang sebelım kami (Allab) mengultus seorang Rasul". (Q.S. Al-Isrra' : 16) ·

Akan tetapi apabila Undang-undang HAM itu diberkalukan surut (atas persetujuan Dewan Perwakilan Rakyat dan Pemerintah ), maka akan membuka wajah baru dalam ketatanegaraan Indonesia maupun Internasional. Dan yang lebih penting lagi bahwa berlaku surutnya itu harus dibatasi mulai dari tahun berapa dari kasus yang mana?

\section{DAFTAR PUSTAKA}

Ali Enran, H Drs \& Nurdin Encep Syarief, Drs, Penuntun Kuliah Pancasila ntuk Perguruan Tinggi, Alfaheta, Jakarta 1994

Al Qur'an dan terjemahannya, Jaya Sakti, Surabaya 1989.

Dalizar, Drs, Konsepsi Al Qur'an tentang Hak Azasi Manusia, Pustaka Al-Husna, Jkarta 1987

Hadisoeprapto Hartono, SH, Dr, Prof, Mengenal Peradilan Tata Usaha negara, Sinar grafika, JAkarta 1993.

Mansoer. Moch Tolchah, Hukum, Negara, Masyarakat, Hak Azasi Manusia dan Islam, Alumni, Jkarta 1979.

Undang - Undang Dasar 1945 beserta penjelasnnya, Mulia Sari, Surabaya 1989. 